\title{
Measurement and Modelling of Particulate Matter Emissions from Harbor Activities at a Port Area: A Case Study of Trabzon, Turkey
}

\author{
Süleyman KÖSE \\ Karadeniz Technical University, Abdullah Kanca Vocational School, Turkey \\ s.kose@ktu.edu.tr; ORCID ID: https://orcid.org/0000-0003-2940-7042
}

Corresponding Author: Süleyman KÖSE

\begin{abstract}
Due to the versatile activities caused by the services provided at the harbor, a large amount of particulate matter is emanated. The health of living things is seriously threatened by the spread of these substances in the air due to the effect of many environmental factors. The size of this threat may reach much higher levels, especially at ports located close to city centers. In this study, at the Trabzon Port area, $\mathrm{PM}_{10}$ and PM (deposited dust) measurements from the harbor activities were carried out at 9 different points between February 2019 and April 2019 and the dispersion of these particulate matter into the environment is analyzed utilizing the ISCST3 (Industrial Source Complex - Short Term) model program. It is detected that the highest amount of measured $\mathrm{PM}_{10}$ (suspended particulate matter) is at the dock 3 with $1.84 \mathrm{mg} / \mathrm{Nm}^{3}$ and the highest amount of PM (deposited dust) is in the dock loading area with $203 \mathrm{mg} / \mathrm{m}^{2}$-day. In the modelling study, it is determined that the particulate matter disperse around an area of $25 \mathrm{~km}^{2}$ in the south direction of the port, and it is concluded that port air quality management will focus on precautions for docks where intensive loading-unloading activities take place.
\end{abstract}

\section{Keywords}

Harbor Activities, Particulate Matter, Emission Modelling, Air Pollution.

\section{Introduction}

The globalization of the world economy, the liberalization of trade and the formation of the international transportation market have contributed greatly to the development of logistics and thus ports have become the key point of world trade [1]. In our world, where global trade is rapidly developing and $90 \%$ of its trade is carried out via sea transportation, the demand for port services has also increased significantly [2]. It is possible to divide port services into two main groups as rendered services to cargos and ships [3]. Services under the two main groups in question can be stated as unloading, loading, pilotage, towage, storage, temporary storage, sheltering, loading-unloading in container, weighing,

To cite this article: Köse, S. (2020). Measurement and Modelling of Particulate Matter Emissions from Harbor Activities at a Port Area: A Case Study of Trabzon, Turkey. Journal of ETA Maritime Science, 8(4), 286-301. To link to this article: https://dx.doi.org/10.5505/jems.2020.49389 
water-electricity, waste and passenger services [4]. Ports, generally established at close regions of urban areas, have a significant impact on the air pollution of their regions [5]. Particularly, loading, unloading, transport and storage of loads such as cement, coal, minerals, soybean and flour cause significant increases in airborne particulate concentrations [6].

Given the fact that more than $50 \%$ of the world's population live in coastal cities [7], emissions from port activities may have a strong impact on the health of coastal communities and the environment [8]. For this reason, in the recent years, many studies have been conducted on the assessment of the impact of port emissions on air quality at a local scale and climate at a regional scale [9][10][11][12][13].

In the case when granule size of the substances (particulates) which is in a solid-state in the atmosphere is less than 300 microns in size, they are called as dust. 50 microns is the limit of vision with the naked eye while the particulates that can reach our lungs are those with a size of 10 microns or less $\left(\mathrm{PM}_{10}\right)$ [14]. Some studies in the literature [15][16][17] indicate that atmospheric particulate matter (PM) in urban areas is linked to the number of daily mortality and hospitalizations as a result of lung and heart diseases.

In 2000, it was calculated that the human lifespan in Europe has been shortened approximately 8.6 months due to PM exposure. Resulting from this particulate exposure, acute upper respiratory tract infections such as sore throat and coughing could be experienced, furthermore it has been concluded that diseases like bronchitis, chronic obstructive pulmonary disease (COPD) and asthma are closely related to high levels of $\mathrm{PM}_{10}$ [18][19].

It has also been reported that the increase in seeking medical advice with cardiovascular system diseases such as vascular occlusion is linked with PM concentration level. Additionally, this exposure to $\mathrm{PM}$ is reported as causing cardiac arrhythmia [20].

The results of a cohort study conducted in USA revealed that the $10 \mu \mathrm{g} / \mathrm{m}^{3}$ increase in PM concentration is associated with a rise in mortality rates by $13 \%$. Another cohort study by American Heart Association has also demonstrated that $6 \%$ increase in mortality rates depending on $10 \mu \mathrm{g} / \mathrm{m}^{3}$ increase in PM concentration [21].

Many diseases caught in Trabzon are due to particulate matter-based air pollution and some of them even resulted in death. About 200 people died in the province due to diseases caused by air pollution between 2005-2007, while approximately 9000 people received inpatient treatment at hospital [22].

When the pollutant amounts from port activities in European harbors were examined, it has been determined that the amount of particulate matter obtained constitutes $40 \%$ of all pollutant amounts [10]. In the literature review conducted in line with this information, many studies have been found on $\mathrm{PM}_{10}$ (particulate matter suspended in the air) emissions resulting from port activities [23][24][25][26][27] [28][29][30], however, it is observed that there has not been any modelling carried out related to the dispersion of emissions to the environment. In addition, when going through the studies examining the emissions of $\mathrm{PM}_{10}$ and PM (deposited dust; including particulates larger than 10 microns) together, although studies have been conducted on $\mathrm{PM}_{10}$ and PM (deposited dust) measurements in the facilities such as cement plant [31][32], thermal power plant [33], mines [34]. Additionally, many studies measuring and modelling $\mathrm{PM}_{10}$ and PM (deposited dust) emissions together from port activities [35][36] could be found in the literature, however the number of studies which integrate modelling, realtime measurement and dispersion is 
scarce. Therefore, in this study, $\mathrm{PM}_{10}$ and PM (deposited dust) measurements were carried out at Trabzon Port by selecting the city of Trabzon, which is located in the centre rather than having the port area close to the city centre, and its effect on the environment is investigated by modelling study. Thanks to this study, it is tried to be find out which region of the port the emissions from port the emissions originating from port activities were more intense. In addition, thanks to the modelling study, revealing the dispersion and impact areas of these emissions is aimed. It is estimated that the study will be effective both in terms of helping port authorities in determining emission sources and guiding the studies to be carried out at other ports.

\section{Methodology}

2.1. Measurement Site and Instruments Used

$\mathrm{PM}_{10}$ and PM (deposited dust) measurement area is the port of Trabzon (shown in Figure 1), which is the most active harbour of the Eastern Black Sea, (between 40 57' 30" North - 41 06' 36" North latitude and 40 02' 30" East - 39 25' $00 "$ East longitudes) in the north east of Turkey. At the port, three separate daily (24 hours) measurements were made for $\mathrm{PM}_{10}$ (suspended particulate matter) and two separate daily measurements were made for PM (deposited dust) for per month. Three different measurements were made for per month at the port at 5 different points for $\mathrm{PM}_{10}$ and two separate measurements at 4 different points for PM (deposited dust). The first period measurements took place between February 3rd 2019 - March 4th 2019 , and the second period measurements took place between March 4th 2019 - April 4th 2019.

Consisting of 9 docks, the port has an annual capacity of 10 million tons of cargo handling and 2500 ships reception per year. In 2019, a total of 1,869,725 tons of unloading operations were performed and 568,950 tons of cargos were loaded. There are annually 5 million tons of cargo

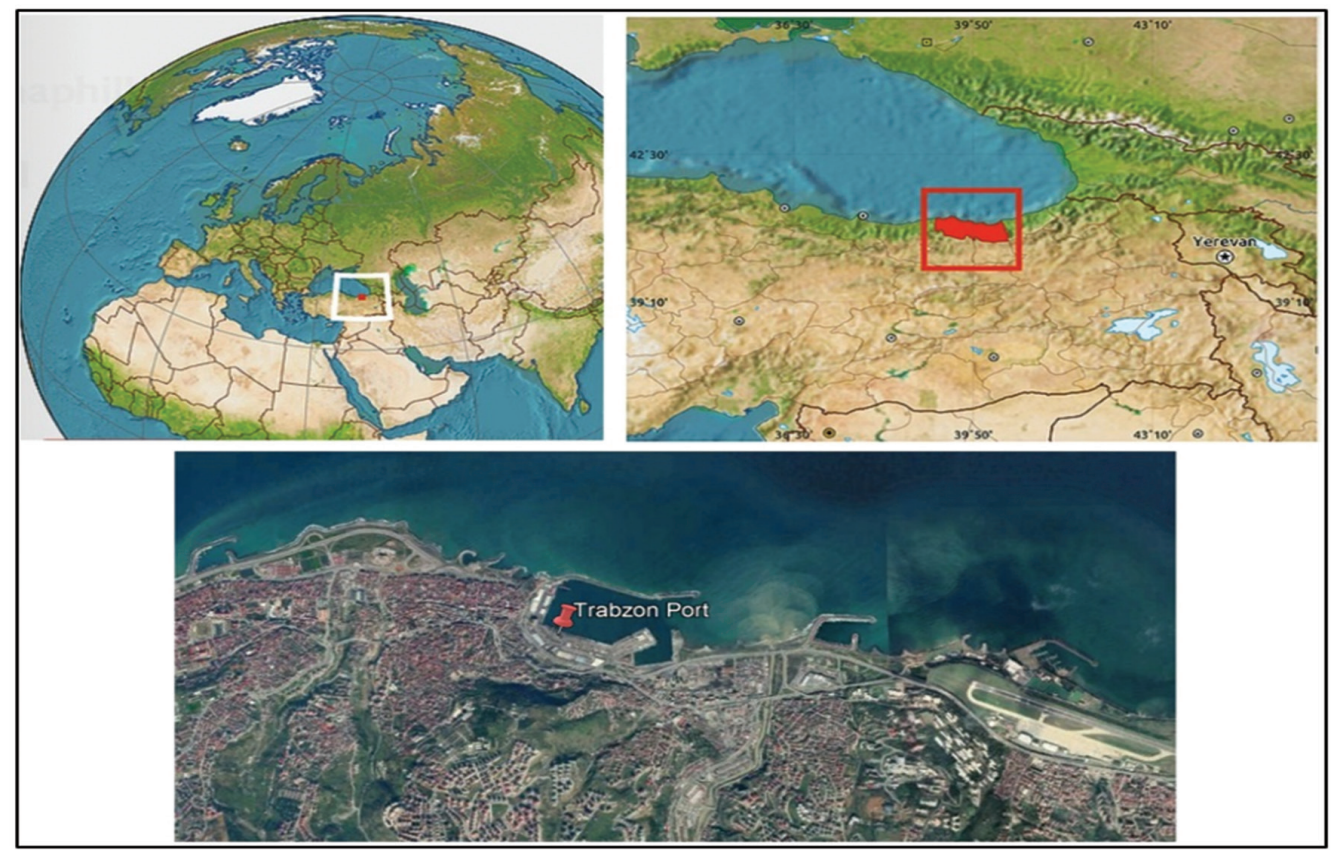

Figure 1. Demonstration of the City Where the Port Chosen as the Study Area on the World Map and Satellite View of the Trabzon Port 
storage area and 250 tons of bilge storage area at the indoor and outdoor storage areas within the port. In addition, 24-hour pilotage and towage services are provided at the port, which has 350,000 TEU container handling and 300,000 TEU container storage area annually. Apart from these, there is a passenger terminal in the port where approximately 50,000 passengers enter and exit annually. In addition to these indicated areas, the free zone of Trabzon province is also located within the port boundaries. In this region there are two covered storage space with a capacity of $11,000 \mathrm{~m}^{2}$ and an open area with a storage capacity of $20,000 \mathrm{~m}^{2}$.

The names of the codes of all emission sources detected, measured and evaluated in this study as a result of onsite inspections within the port and the parameters measured in these sources are given in Table 1. Moreover, the locations where $\mathrm{PM}_{10}$ measurement areas located in the port's general settlement are shown in Figure 2 with satellite photographs, and the locations where the PM (deposited dust) measurement sites were located in the general location of the port are shown in Figure 3 with satellite photographs.

Table 1. Measured Emission Sources

\begin{tabular}{|c|l|c|c|}
\hline \multirow{2}{*}{ Code } & \multicolumn{2}{|c|}{ Name of Emission Source } & \multicolumn{2}{c|}{ Parameters } \\
\cline { 3 - 4 } & & PM $_{10}$ & PM (deposited dust) \\
\hline 1 & Stock Area (warehouse area) & $\mathrm{x}$ & - \\
\hline 2 & Dock 3 (loading-unloading) & $\mathrm{x}$ & - \\
\hline 3 & Dock 4 (loading-unloading) & $\mathrm{x}$ & - \\
\hline 4 & Beside Weighbridge & - & - \\
\hline 5 & Truck Crossing Road (small port) & - & $\mathrm{x}$ \\
\hline 6 & Beside Guest Parking Area & - & $\mathrm{x}$ \\
\hline 7 & Front of Dock 3 & - & $\mathrm{x}$ \\
\hline 8 & Next to Loading Area 4-5 & & \\
\hline 9 & Bilge Area & & \\
\hline
\end{tabular}

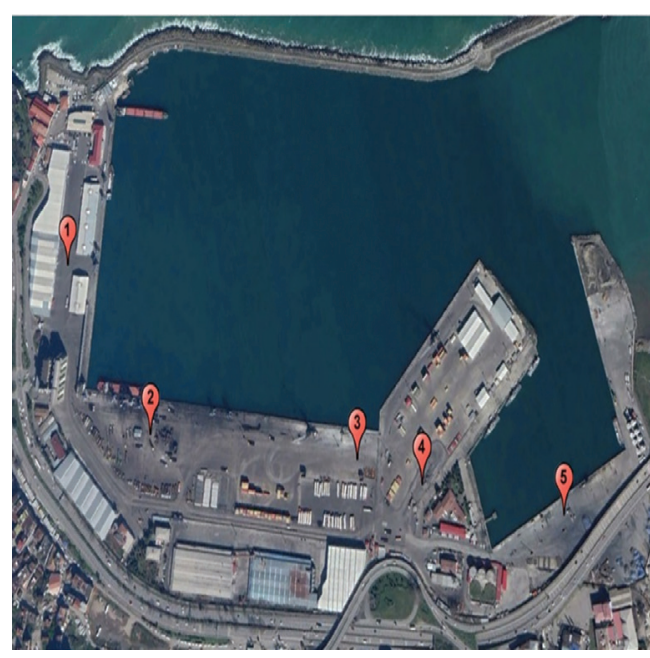

Figure 2. $P M_{10}$ Measuring Points

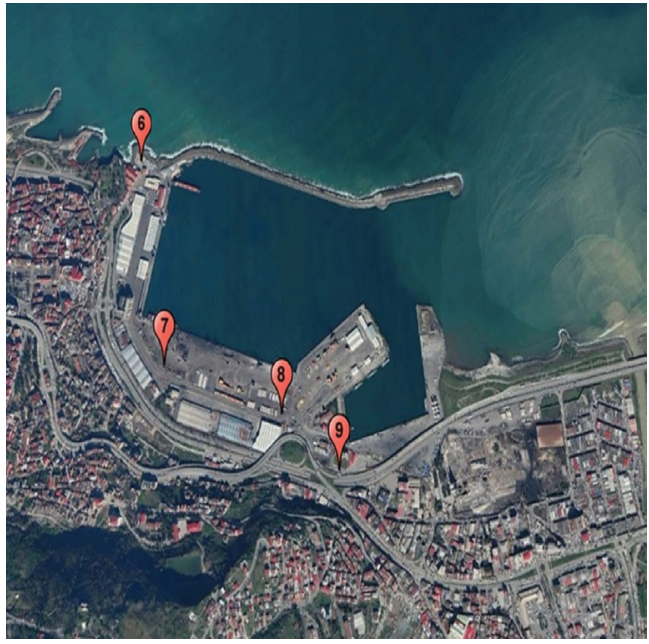

Figure 3. PM (deposited dust) Measuring Points 
Official permissions for performing necessary measurements were granted from port authority prior to the study and the researcher also contacted with port management company and guaranteed their support for the study.

\subsection{1. $\mathrm{PM}_{10}$ Sampling Method}

EPA 40 CFR PART 50, one of the gravimetric measurement methods, is a widely used method for the measurement of particulates called $\mathrm{PM}_{10}$, which exist in outdoor air as suspended in solid state. The sampling process was carried out by determining the most suitable distances for the emission sources specified in Figure 4 (1)-(2)-(3)-(4)-(5).

The $\mathrm{PM}_{10}$ absorption nozzle of the Zambelli Iso Plus 6000 dust sampling device was located at a certain height and the device was operated. The air sample taken at constant flow rate at appropriate points around ambient dust sources was passed through the appropriately conditioned filter. It held on to the suspended $\mathrm{PM}_{10}$ filter in the environment. After the measurement was concluded, the measurement data was taken from the device and recorded on the measurement form. The filter used in the measurement was carefully removed, placed in a petri dish and brought to the laboratory by labelling. The filters used in the sampling were weighed by waiting 24 hours under weighing room conditions $\left(20^{\circ} \mathrm{C} \pm 1{ }^{\circ} \mathrm{C}\right.$ temperature and $50 \% \pm 5 \%$ humidity). Dust concentration was calculated as $\mathrm{mg} / \mathrm{Nm}^{3}$ by proportioning weighing results in to the volume of air drawn. $\mathrm{PM}_{10}$ measurement results were obtained by performing this process between February and April 2019 3 times for each measurement point and 15 times in total.

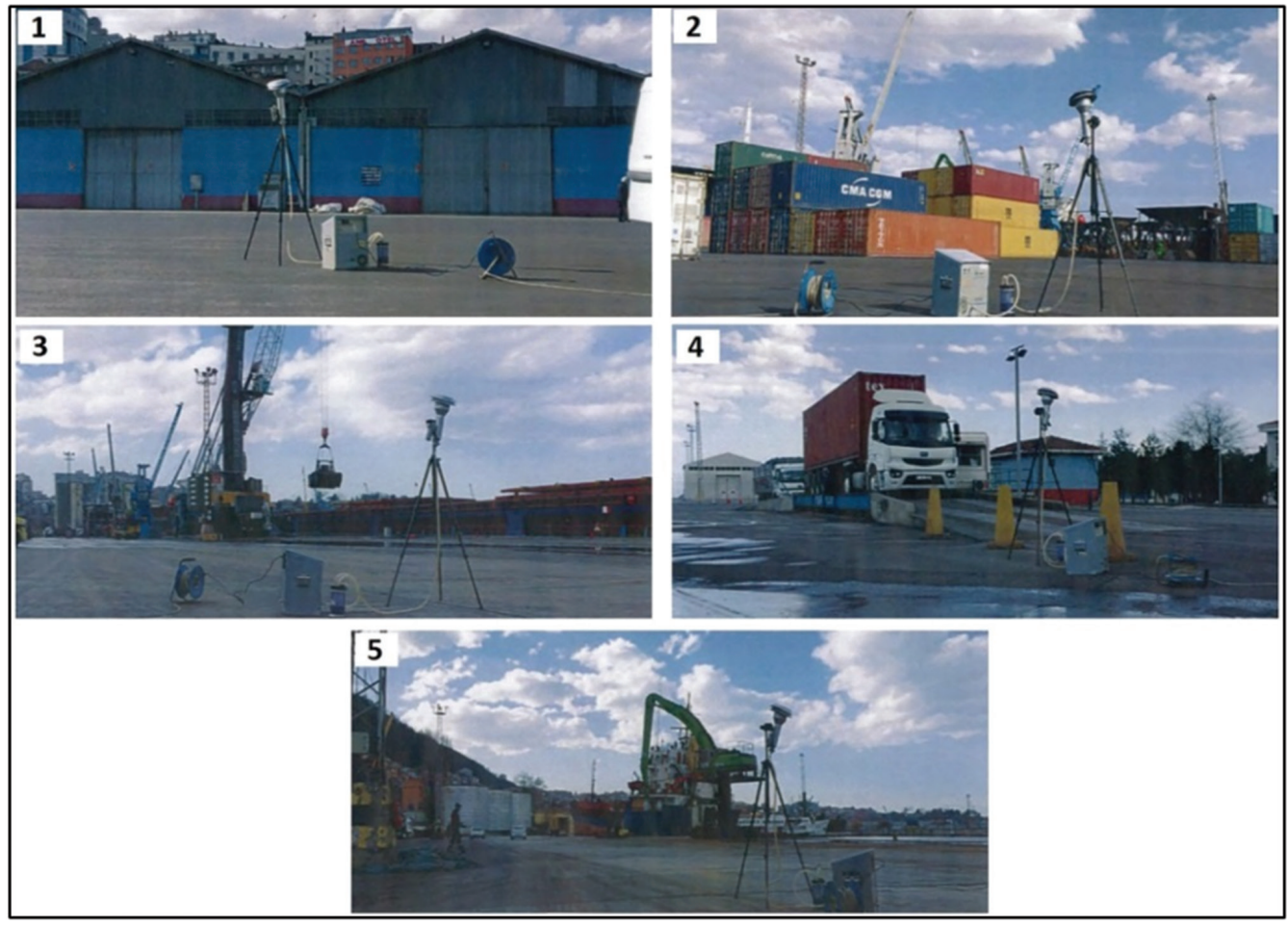

Figure 4. $P M_{10}$ Measuring Points, (1) Stock Area, (2) Dock 3, (3) Dock 4, (4) beside Weighbridge, (5) Truck Crossing Road 


\subsubsection{PM (Deposited dust) Sampling Method}

TS 2341 standard, which is a gravimetric measurement method, has been taken as basis in collecting PM (deposited dust) samples. This standard comprises methods for the construction, installation and operation of the sediment collection device, which is used to collect and measure deposited dust in the atmosphere, that collapse with their own weight or rain, and so on.

The deposited dust unit used in sampling, which is placed at points in Figure 5 (6)-(7)(8)-(9), generally consists of: stand, sump case, collecting bottle and connecting pipes. The stand was approximately $1350 \mathrm{~mm}$ tall and the protective cage against birds was selected with an aperture size of approximately $0.7 \mathrm{~mm}$. The stand was fixed with a suitable fastener to prevent the collection bottles from falling off the shelves where they were located. The sump case was selected from a suitable plastic material that was resistant to chemicals and not charged with static electricity.
Each sump case was marked with a serial number, with getting a conversion factor $(\mathrm{F})$ for each container, and the calculations were made over this $\mathrm{F}$ factor. The conversion factor was calculated from the average effective diameter of the sump case. The average of these 24 measurements was taken at 12 points around the container by measuring the inner and outer diameters. Thus, the $\mathrm{D}$ diameter required for the conversion factor was obtained. The dimensions were rounded up to the nearest millimetre and factor $(F)$ was calculated as $1 / \mathrm{m}^{2}$ with the following formula. When the weight (milligrams) of the collected sediment was multiplied by this factor, the result was milligrams per square meter $\left(\mathrm{mg} / \mathrm{m}^{2}\right)$.

$$
F=\frac{127,3 \times 10^{4}}{D^{2}}
$$

The measurement period was 2 (two) measurements per month at the points specified in Figure 5 and at specified periods, and a total of 2 (two) months. The average

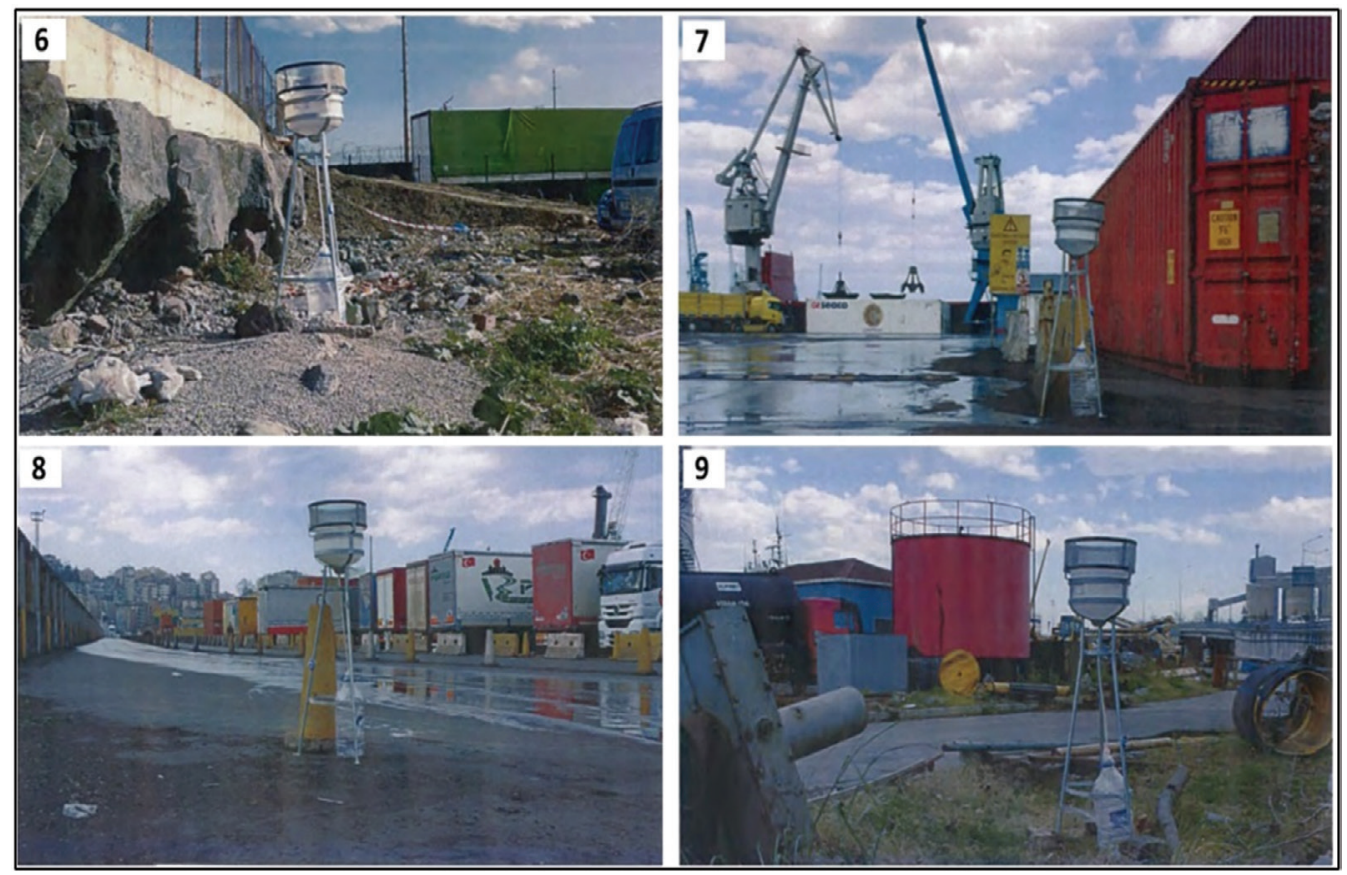

Figure 5. PM (deposited dust) Measuring Points, (6) beside Guest Parking Area, (7) front of Dock 3, (8) next to Loading Area 4-5, (9) Bilge Area 
amount of dust settled in one day was calculated by dividing the monthly values by the number of days.

\subsection{Air Quality Modelling}

The air quality modelling process is prepared using the ISCST3 (Industrial Source Complex- Short Term) model program approved by the U.S. Environmental Protection Agency. The ISCST3 model is an internationally recognised modelling program used worldwide by many researchers, supervisory and authority bodies to predict pollutant concentrations. Gaussian Distribution [37] forms the basis of the model. With this model, many emission sources can be modelled simultaneously or separately. ISCST3 calculates the distribution of emissions from sources around these group of resources, long-term concentrations at ground level or at desired height, and groundlevel precipitation.

In order to use the modelling program, source, emission data and meteorological and topographical data were inputted into the program. The meteorological data were hourly wind blowing directions and frequencies, hourly wind speeds, average hourly temperatures, daily average mixture height and stability class values. The evaluation of stability classes is made according to the stability categories of Pasquill [38]. In addition, in accordance with meteorological data, wind rose was created based on the direction of wind and the number of blows. For topographical data entered in the model, topographic map of the region was used. Cartesian and polar coordinate systems were inputted into the modelling program. The examined region was divided into $500 \mathrm{~m}$. intervals ( $\mathrm{x}-\mathrm{y}$ axes) in the range of $0-2 \mathrm{~km}$ and the average concentration values were determined at the designated receiving points. In order to see the effect of the buildings around the port to dispersion, the heights of the buildings around the port as well as topography were also typed into the model.

The concentration areas were calculated for each source and thrown into a common polar and Cartesian coordinate system. Finally, emissions from all sources were collected. The model also could take emissions from volume and surface area into account. As a result of operating the model, monthly and annual average PM concentrations amounts were obtained at the port and the annual distribution of these PM concentrations was determined.

\section{Results and Discussion}

\subsection{Particulate Matter Measurement Results}

The first, second and third measurement results obtained from 5 sources, and the mean and limit value of these values are shown in Table 2 for the emission of $\mathrm{PM}_{10}$ within two months.

Table 2. $P M_{10}$ Measurements Results

\begin{tabular}{|c|c|c|c|c|c|c|}
\hline \multirow[b]{2}{*}{ Code } & \multirow[b]{2}{*}{ Name of the Source } & \multicolumn{3}{|c|}{ Measurements (mg / $\mathrm{Nm}^{3}$ ) } & \multirow{2}{*}{$\begin{array}{c}\text { Average } \\
\text { Value } \\
\left(\mathrm{mg} / \mathrm{Nm}^{3}\right)\end{array}$} & \multirow{2}{*}{$\begin{array}{c}\text { Limit } \\
\text { Value }(\mathrm{mg} \\
\left./ \mathrm{Nm}^{3}\right)\end{array}$} \\
\hline & & $\begin{array}{c}1 \text { st } \\
\text { measurement }\end{array}$ & $\begin{array}{c}\text { 2nd } \\
\text { measurement }\end{array}$ & $\begin{array}{c}\text { 3rd } \\
\text { measurement }\end{array}$ & & \\
\hline 1 & $\begin{array}{l}\text { Stock Area } \\
\text { (warehouse area) }\end{array}$ & 1.50 & 1.36 & 1.44 & 1.43 & 3.0 \\
\hline 2 & $\begin{array}{l}\text { Dock No } 3 \text { (loading- } \\
\text { unloading) }\end{array}$ & 1.56 & 1.84 & 1.70 & 1.70 & 3.0 \\
\hline 3 & $\begin{array}{l}\text { Dock No } 4 \text { (loading- } \\
\text { unloading) }\end{array}$ & 1.84 & 1.36 & 1.50 & 1.57 & 3.0 \\
\hline 4 & Beside Weighbridge & 1.78 & 1.48 & 1.58 & 1.61 & 3.0 \\
\hline 5 & $\begin{array}{l}\text { Truck Crossing Road } \\
\text { (small port) }\end{array}$ & 0.90 & 1.08 & 0.78 & 0.92 & 3.0 \\
\hline
\end{tabular}


In the examination, it is detected that the highest value for the first measurement was at dock no. 4 with $1.84 \mathrm{mg} / \mathrm{Nm}^{3}$. It is seen that the lowest $\mathrm{PM}_{10}$ concentration was on the truck crossing road with 0.90 $\mathrm{mg} / \mathrm{Nm}^{3}$. When checking the other two measurement results, it is determined that the lowest values obtained were in the same direction with the first measurements, but the highest values were due to the dock 3 . When examining the lengths and depths of docks 3 and 4; it is determined that the dock number 3 was 580 meters long and $10 \mathrm{~m}$ deep and the dock no. 4 was $290 \mathrm{~m}$. long and $12 \mathrm{~m}$. deep. Whereas the dock was capable of accepting more ships than the dock 4 at once, the ships with more draft could berth to the dock 4. These two conditions are factors that affect the increase of handling activities and accordingly increase of $\mathrm{PM}_{10}$ emissions. As it can be seen from these results while the first measurement was carried out, more ships were loaded and unloaded at dock 4; dock 3, which had the capacity to accept more ships was working more actively during the period of the other two measurements. As a result of the results obtained, we can clearly say that the dock length and dock depth directly affected the $\mathrm{PM}_{10}$ concentration formed in the port. When the average values are taken into consideration, it is understood that the length of the dock is more effective than the depth of the dock in terms of the effect on the emission amount.

Considering the wind direction in the port, it is determined that these concentrations did not exceed the Turkish air quality limit value of $3.0 \mathrm{mg} / \mathrm{Nm}^{3}$ as a result of the measurement values obtained at 5 points 3 meters away from the dust source $\left(\mathrm{PM}_{10}\right)$ (suspended particulate matter). It is also observed that the European $\mathrm{PM}_{10}$ concentration limit value, which was $50 \mu \mathrm{g} / \mathrm{m}^{3}$, had not been exceeded. Although the limit values had not been exceeded, if we evaluated the air quality of the region in terms of the location of the port, the fact that a port located in the centre of the city polluted the air that much might cause problems to be concerned with human health.

The mean and limit values are shown in Table 3 with the results of 2 periods of PM (deposited dust) in 4 different points at the port. When the first and second period measurements are examined, it is determined that the amount of deposited dust beside the dock 3 and the loading area $4-5$ which were the active areas of the port, was much more than the bilge area and the harbour's guest car park which were in the scope of harbour. It is clearly seen that the highest PM (deposited dust) value was in the 8 -coded region in the 2 nd period measurements with $203 \mathrm{mg} / \mathrm{m}^{2}$-day and the lowest value was in the 6 -coded region with the $80 \mathrm{mg} / \mathrm{m}^{2}$-day. As it can be clearly understood from these results, although the amount of PM (deposited dust) caused by the port operations had affected the port's impact area, it is determined that the

Table 3. PM (deposited dust) Measurement Results

\begin{tabular}{|c|c|c|c|c|c|}
\hline Code & $\begin{array}{c}\text { Name of the } \\
\text { Source }\end{array}$ & $\begin{array}{c}\text { 1st } \\
\text { Measurements } \\
\text { (mg/m²-day) }\end{array}$ & $\begin{array}{c}\text { 2nd } \\
\text { Measurements } \\
\left.\text { (mg/m } / \mathrm{m}^{2} \text {-day }\right)\end{array}$ & $\begin{array}{c}\text { Average Value } \\
\text { (mg/m²-day) }\end{array}$ & $\begin{array}{l}\text { Limit Value } \\
\left(\mathrm{mg} / \mathrm{m}^{2} \text {-day) }\right.\end{array}$ \\
\hline 6 & $\begin{array}{l}\text { Beside Guest } \\
\text { Parking Area }\end{array}$ & 80 & 82 & 81 & 450 \\
\hline 7 & Front of Dock 3 & 191 & 185 & 188 & 450 \\
\hline 8 & $\begin{array}{l}\text { Next to Loading } \\
\text { Area 4-5 }\end{array}$ & 185 & 203 & 199 & 450 \\
\hline 9 & Bilge Area & 86 & 84 & 85 & 450 \\
\hline
\end{tabular}


significant amount of it accumulated in the active areas of the port.

It is determined that the limit value of $450 \mathrm{mg} / \mathrm{m}^{2}$-day was not exceeded, when the results of the deposited dust measurements carried out in the port are evaluated in accordance with the Turkish Air Pollution Regulation.

Loading, unloading and storing operations that might cause dust emission are carried out at the port. Emission factors are calculated based on the mass flow rate of the measurements made, based on the hourly production amount of 2,248 tons/ hour. Emission factors are determined as $0.005 \mathrm{~kg} /$ ton for loading and unloading and $2.9 \mathrm{~kg}$ dust/ha per day for storage. In accordance with the specified processes, mass flow is found to be $11.24 \mathrm{~kg} / \mathrm{hour}$ for loading and unloading, and $0.15 \mathrm{~kg} /$ hour for 1.3-hectare (ha) storage. The total amount of emissions discharged to the atmosphere from the places other than the chimney is determined as $22.63 \mathrm{~kg} /$ hour. This is approximately 23 times over the limit value determined by the Turkish Air Pollution Regulation as $1.0 \mathrm{~kg} /$ hour. As a consequence of this result, it is clearly seen that the dust emissions caused by the operation in the ports reached very dangerous levels.

\subsection{Air Quality Model Results}

As a result of the researches, climate and different factors related to climate and occupy an important portion of the amount of air pollution, along with some other geographical factors such as geographical location and topography. It is possible to sort these climate-related factors affecting air pollution in the form of wind, atmospheric stability and thermal inversions, topography [39]. In this respect, the port region wind rose created by using the data obtained from the meteorology station is shown in Figure 6.

As a result of the model study, when we examine the wind speed and directions that were effective in emission distributions; according to the specified measuring station data; the average wind speed was of $1.8 \mathrm{~m} / \mathrm{s}$ per year. Wind speeds ranged from $1.5 \mathrm{~m} / \mathrm{s}$ to $1.9 \mathrm{~m} / \mathrm{s}$ in different months. The first-degree prevailing wind direction in the region was the south-southwest (SSW) direction with a breeze number of 3477 .

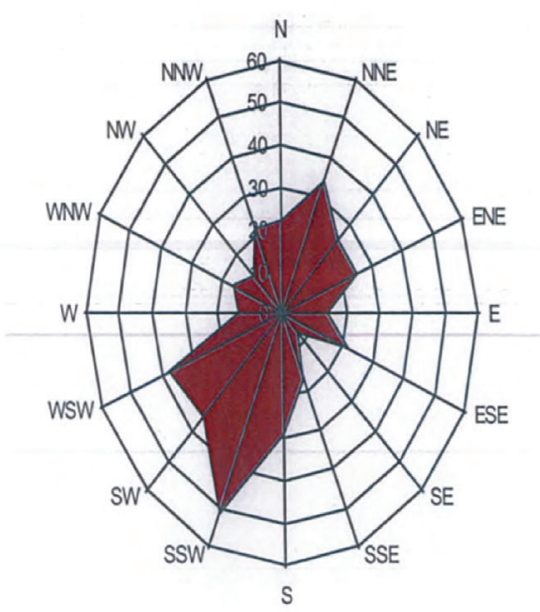

Figure 6. Trabzon Port Region Wind Rose

Monthly emission values and the annual average emission value obtained as a result of the air quality modelling study conducted to determine the concentrations of dust emissions emitted from the port around the port are given in Table 4. Higher values were obtained in many points due to the increase in $\mathrm{PM}_{10}$ concentrations in the air and dust emissions from the ground, especially in the summer with the decrease of precipitation in the region. However, it is thought that the high values in the winter months such as December and January, which are determined from time to time, might be due to household heating aroused from the sampling point in the settlement area and also due to the increase in the number of ships arriving at the port during these periods.

In addition, when the monthly PM concentrations values obtained as a result 
of the air quality modelling study given in Table 4 are examined, it is clearly seen that the lowest value is the value in April, which is one of the most precipitation months of the province with $9,2180 \mathrm{mg} / \mathrm{m}^{2}$-day. As a result of these values, it can be predicted that seasonal changes as well as the number of ships affect the amount of dust emission at the port. Although developed

Table 4. Amounts of PM Deposition Obtained by Air Quality Modelling

\begin{tabular}{|c|c|}
\hline Months & $\begin{array}{c}\text { Particulate Matter } \\
\left.\text { (mg/ } \mathbf{m}^{\mathbf{}} \text {-day }\right)\end{array}$ \\
\hline January & 22,60 \\
\hline February & 17,07 \\
\hline March & 18,64 \\
\hline April & 9,21 \\
\hline May & 13,79 \\
\hline June & 15,69 \\
\hline July & 17,34 \\
\hline August & 28,64 \\
\hline September & 22,71 \\
\hline October & 24,85 \\
\hline November & 21,67 \\
\hline December & 25,69 \\
\hline Annual Average & 21,33 \\
\hline
\end{tabular}

countries have recently noticed the global damages of fossil fuels, the widespread use of these fuels still continues. Coal firing causes the release of dust pollutants such as particulate matter (PM) into the air [40]. In Turkey, which is poor in terms of oil and gas resources, the situation is progressing with the use of low-quality lignite in energy production. China imports the world's largest stone coal, and Turkey is the 7th largest importer. Turkey is the country planning the most lignite and stone coalfired thermal power plants in the European Region in terms of number and capacity [40]. Therefore, it is understood that the emission value, which had an average annual value of $21,3335 \mathrm{mg} / \mathrm{m}^{2}$-day, is very close to the values in September, November, December and January, and emissions from household heating in the region had a significant impact on port emission values.

When the obtained results were compared with the measurement results made in a coal-fired thermal power plant, it was determined that the measurement results obtained at the port were almost half lower than the measurement results at the thermal power plant (the mean PM measurement results between 2013 - 2017

\section{The Amounts of PM}

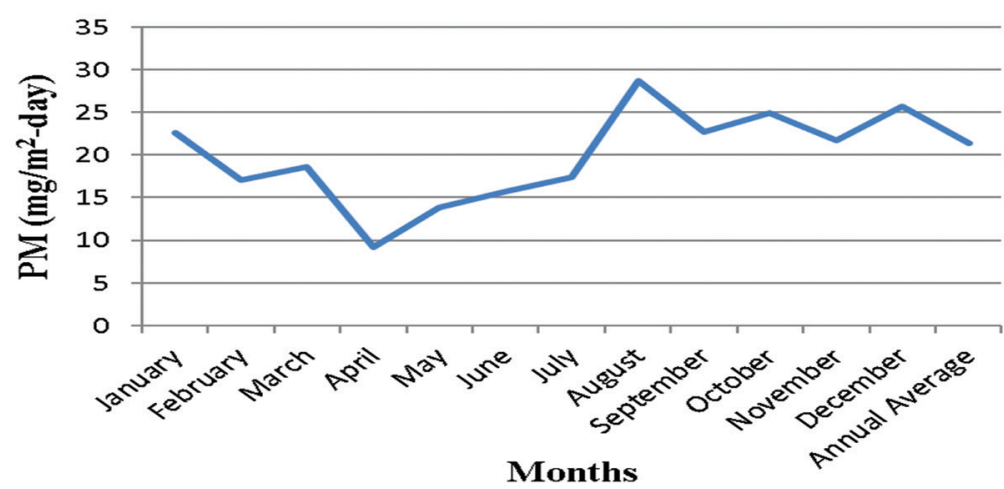

Figure 7. Monthly and Annual Average Amount of PM Graph 
for 4 points were $69.41 ; 30.32 ; 30.97$; and $26.44 \mathrm{mg} \mathrm{m}^{2}$ day respectively [33]).

The distribution graph obtained as a result of the air quality modelling study conducted to determine the distribution of dust concentrations emitted from the port around the port is given in Figure 8. The wind rose prepared for annual blow numbers and directions where the wind came from and the distribution graph prepared for annual average concentrations shows that the model consequences gave results consistent with the wind rose.

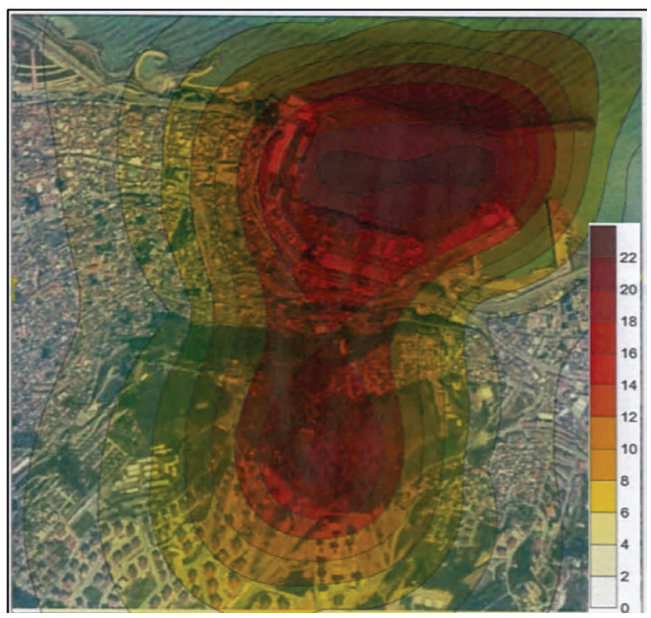

Figure 8. The Particulate Matter Concentration Map

In the examination made on the particulate matter concentration map, it is determined that dust emissions affected an area of approximately $25 \mathrm{~km}^{2}$. As it can be seen in Figure 9, the port subject to the study is one of the rare ports in the centre of the city where it is located and so close to the city centre. The $25 \mathrm{~km}^{2}$ impact area mentioned above threatens the region where people live intensely and have the highest average population during the day.

There is an international main road with an average of 50 thousand vehicles passing annually, just 100 meters from the south direction of the port area subject to the study. PM ${ }_{10}$ PM (deposited dust) and VOC (Volatile Organic Compounds) emanating

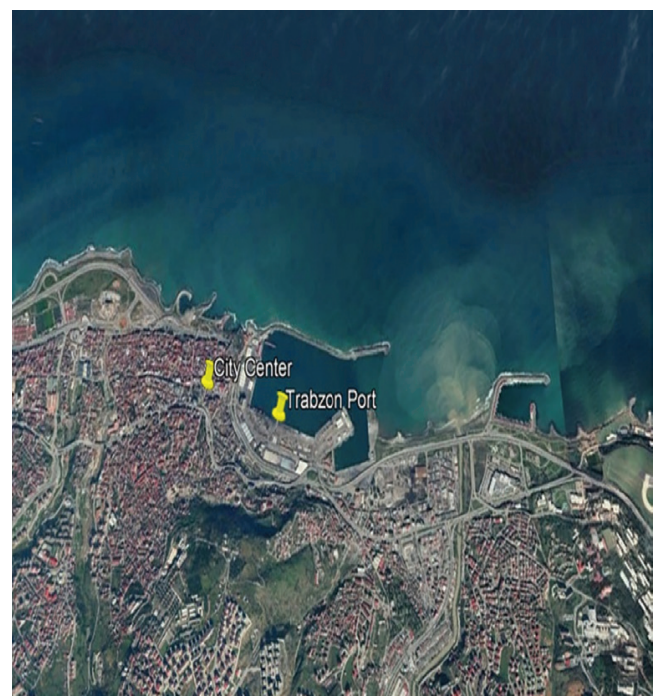

Figure 9. The Satellite Image of the Closeness of the Port to the City Centre

from vehicles are important sources of pollution in the urban air. According to TUIK (Turkish Statistical Institute) 2019 data, the exhaust emissions of vehicles which are in traffic create a significant amount of air pollution in our country where there are approximately 7.5 million vehicles over the age of 16 [41]. According to this information, when we think about how the emissions originating from the traffic are distributed in the same direction by combining with the emissions flowing out from the port, it is clear how much the port area poses a human health risk.

Moreover, when the data obtained from the Trabzon-Meydan (Square) measurement station, which also includes the Port region, it is determined that in 323-day measurements from 2019, $\mathrm{PM}_{10}$ values are found to exceed the EU limit value in 94 days [42]. When the values measured in the specified station are analysed, it is determined that approximately $32 \%$ of these values are emissions originating from the port. In our world where approximately 7 million deaths are caused by both outdoor and indoor air pollution each year [43], the contribution of ports to this pollution is at a considerable level. 


\section{Conclusions}

As a result of operations such as loading, unloading and storage in Trabzon Port and other port activities that take place outside of these, a significant amount of particulate matter (PM) is emitted to the atmosphere. The loading and unloading activities carried out at the dock had the most profound effect on the $\mathrm{PM}_{10}$ values obtained at the port area. In addition, storage and transportation activities in the port caused $\mathrm{PM}_{10}$ to occur almost as much as loading and unloading activities. These activities that we mentioned also affected PM (deposited dust) emissions, another type of dust. It is determined that PM (deposited dust), which occurred as a result of the activities taking place at the quay, mostly accumulated in the close regions of the quays. It is seen that this effect reduces by almost $50 \%$ in the car park and bilge area, which are the impact area of the port.

With the air quality distribution modelling, which is the result of combining the port region with meteorological and topographic data, it is determined that the data obtained from the sources mentioned in the port is affected by dust emitted into the atmosphere as a result of port activities of a region of $25 \mathrm{~km}^{2}$ including the port. While approximately $2 \mathrm{~km}^{2}$ of this area constituted the port area, the remaining part is located in the central region of the city. Dust emissions, which can reach approximately $3 \mathrm{~km}$ in the east and west directions, can also reach $5 \mathrm{~km}$ in the south direction according to the model results. The region, which is stated as the city centre and a high population zone, is located at a distance of 300 meters in the south direction of the harbour, showing that these emissions are highly threatening the living life. Based on the result that the dispersion distances obtained at the selected port will increase or decrease depending on the change of load amounts and wind speeds at ports in other regions, when choosing a port establishment, we can make an apparent deduction that the distance of the port from the city centre is one of the most important factors to be considered.

As a result of the study, it is made out that the wind is the most influential in the dispersion of the dust, which is caused by port activities. At all ports and especially at ports like Trabzon Port, where loadingunloading, storage and transportation of cargos such as coal, cement and grain are the most frequent by ships, these activities may result in generating high levels of dust. In order to reduce dust emission, measures such as placing wind cutting boards at the port area, covering the materials stored out in the open, keeping the upper layers of the materials humid, ensuring regular watering and cleaning of the port roads are required.

Using cyclone separators in port buildings with coal fired central heating systems or making use of alternative energy sources such as electricity or natural gas for heating would decrease the amount of PM emissions. Achieving thermal insulation is also essential for reducing PM emissions. In this way, fuel consumption could be decreased and less air pollutants would be released into the atmosphere. Along with these, green wave can be applied on the road near the port for a continuous traffic flow in order to reduce these emissions caused by vehicles, which are occurred generally on acceleration and braking.

In line with this study, estimation of future emissions can be carried out by using the number of ships arriving the port and the data from cargo handling with regression analysis method. Accordingly, necessary preventions could be taken for potentially more serious air pollution threats.

\section{Acknowledgement}

For the estimations on this study, the authorized personnel certificate on emission measurement has been taken from The Turkish Ministry of Environment and 
Urbanization. We are also thankful to NEVA Laboratory employees for their great effort on each measurement.

\section{References}

[1] Zhao M, Zhang Y, MaaW, Fu Q, Yang X, Li C, Zhou B, Yua Q, Chen L (2013) Characteristics and ship traffic source identification of air pollutants in China's largest port. Atmospheric Environment, 64, 277286. https://doi.org/10.1016/j. atmosenv.2012.10.007.

[2] Xu, Y., Stanley, H. E., \& Su, Y. (2019). Econometric Analysis on Development of Port Logistics Industry in Zhanjiang. In 2018 International Conference on Mathematics, Modeling, Simulation and Statistics Application (MMSSA 2018) (pp. 1951-6851). Shangai: Atlantis Press. https://doi. org/10.2991/mmssa-18.2019.30.

[3] Le, D. N., Nguyen, H. T., \& Truong, P. H. (2019). Port logistics service quality and customer satisfaction: Empirical evidence from Vietnam. The Asian Journal of Shipping and Logistics. https://doi.org/10.1016/j. ajsl.2019.10.003.

[4] Žgaljić, D., Tijan, E., Jugović, A., \& Poletan Jugović, T. (2019). Implementation of Sustainable Motorways of the Sea Services Multi-Criteria Analysis of a Croatian Port System. Sustainability, 11(23), 6827. https://doi.org/10.3390/ su11236827.

[5] Alastuey, A., Moreno, N., Querol, X., Viana, M., Artiñano, B., Luaces, J. A., ... \& Guerra, A. (2007). Contribution of harbour activities to levels of particulate matter in a harbour area: Hada ProjectTarragona Spain. Atmospheric Environment, 41(30), 63666378. https://doi.org/10.1016/j. atmosenv.2007.03.015.
[6] Martín, F., Pujadas, M., Artinano, B., Gómez-Moreno, F., Palomino, I., Moreno, N., ... \& Guerra, A. (2007). Estimates of atmospheric particle emissions from bulk handling of dusty materials in Spanish Harbours. Atmospheric Environment, 41(30), 63566365. https://doi.org/10.1016/j. atmosenv.2006.12.003.

[7] Gupta, A. K., Gupta, S. K., \& Patil, R. S. (2005). Environmental management plan for port and harbour projects. Clean Technologies and Environmental Policy, 7(2), 133-141. https://doi.org/10.1007/s10098004-0266-7.

[8] Sorte, S., Arunachalam, S., Naess, B., Seppanen, C., Rodrigues, V., Valencia, A., Borrego, C., Monteiro, A., (2019). Assessment of source contribution to air quality in an urban area close to a harbor: Case-study in Porto, Portugal. Science of the Total Environment, 662, 347-360. https://doi.org/10.1016/j. scitotenv.2019.01.185.

[9] Rowangould, D., Rowangould, G., \& Niemeier, D. (2018). Evaluation of the Health Impacts of Rolling Back a Port Clean Trucks Program. Transportation Research Record, 2672(11), 53-64. https://doi. org/10.1177/0361198118793328.

[10] Sorte, S., Rodrigues, V., Borrego, C., \& Monteiro, A. (2019). Impact of harbour activities on local air quality: A review. Environmental Pollution, 113542. https://doi.org/10.1016/j. envpol.2019.113542.

[11] Bermúdez, F. M., Laxe, F. G., \& Aguayo-Lorenzo, E. (2019). Assessment of the tools to monitor air pollution in the Spanish ports system. Air Quality, Atmosphere \& Health, 12(6), 651-659. https:// doi.org/10.1007/s11869-01900684-x. 
[12] Mocerino, L., Murena, F., Quaranta, F., \& Toscano, D. (2020). A methodology for the design of an effective air quality monitoring network in port areas. Scientific Reports, 10(1), 1-10. https://doi.org/10.1038/s41598019-57244-7.

[13] Gonzalez-Aregall, M., \& Bergqvist, R. (2020). Green port initiatives for a more sustainable port-city interaction: The case study of Barcelona. In Maritime Transport and Regional Sustainability, 109-132. https://doi.org/10.1016/B978-0-12819134-7.00007-1.

[14] Kamila, W., Wioletta, R. K., Krzysztof, L., Karolina, K., \& Grzegorz, M. (2018). Health risk impacts of exposure to airborne metals and benzo (a) pyrene during episodes of high PM10 concentrations in Poland. Biomedical and Environmental Sciences, 31(1), 23-36. https://doi.org/10.3967/ bes2018.003.

[15] Schwartz, J., Dockery, D.W., Neas, L.M., (1996). Is Daily mortality associated specifically with fine particles? Journal of Air and Waste Management Association, 46, 927-939. https://doi. org/10.1080/10473289.1996.10467 528.

[16] Dockery, D., \& Pope, A., (1996). Epidemiology of acute health effects: summary of time-series studied. In Editor (J.D., Spengler, \& R, Wilson), En Particles in Our Air: Concentration and Health Effects. (pp. 123-147). Cambridge: Harvard University Press.

[17] Khaniabadi, Y. O., Goudarzi, G., Daryanoosh, S. M., Borgini, A., Tittarelli, A., \& De Marco, A. (2017). Exposure to PM10, NO2, and 03 and impacts on human health. Environmental science and pollution research, 24(3), 2781-2789. https:// doi.org/10.1007/s11356-016-80386.
[18] MacNee, W., \& Donaldson, K. (1999). Particulate air pollution: injurious and protective mechanisms in the lungs. In Editor (Stephen T. Holgate, Hillel S. Koren, Jonathan M. Samet, \& Robert L. Maynard), Air Pollution and Health (pp. 653-672). Academic Press. https:// doi.org/10.1016/B978-0123523358/50105-8.

[19] Uherek, E., Halenka, T., Borken-Kleefeld, J., Balkanski, Y., Berntsen, T., Borrego, C., ... \& Melas, D. (2010). Transport impacts on atmosphere and climate: Land transport. Atmospheric environment, 44(37), 4772-4816. https://doi.org/10.1016/j. atmosenv.2010.01.002.

[20] Polichetti, G., Cocco, S., Spinali, A., Trimarco, V., \& Nunziata, A. (2009). Effects of particulate matter (PM10, PM2. 5 and PM1) on the cardiovascular system. Toxicology, 261(1-2), 1-8. https://doi. org/10.1016/j.tox.2009.04.035.

[21] Lopez,M.T.,Zuk, M., Garibay, V., Tzintzun, G., Iniestra, R., \& Fernandez, A. (2005). Health impacts from power plant emissions in Mexico. Atmospheric environment, 39(7), 1199-1209. https://doi.org/10.1016/j. atmosenv.2004.10.035.

[22] Türk, A., Y., Kavraz, M. \& Türk, M., H., (2008). Trabzon Kentinde Hava Kirliliği ve İnsan Sağlığına Etkileri. Hava Kirliliği ve Kontrolü Ulusal Sempozyumu (pp. 810821). Hatay.

[23] Gupta, A. K., Patil, R. S., \& Gupta, S. K. (2002). Emissions of gaseous and particulate pollutants in a port and harbour region in India. Environmental monitoring and assessment, 80(2), 187-205. https://doi. org/10.1023/A:1020641014104.

[24] Gupta, A. K., Patil, R. S., \& Gupta, S. K. (2004). A statistical analysis of particulate data sets for Jawaharlal Nehru port and surrounding harbour region in India. Environmental monitoring and assessment, 95(1-3), 295-309. https://doi.org/10.1023/ B:EMAS.0000029910.17854.c4. 
[25] Moreno, N., Alastuey, A., Querol, X., Artinano, B., Guerra, A., Luaces, J. A., ... \& Basora, J. (2007). Characterisation of dust material emitted during harbour operations (HADA Project). Atmospheric Environment, 41(30), 63316343.9. https://doi.org/10.1016/j. atmosenv.2007.03.028.

[26] Joseph, J., Patil, R. S., \& Gupta, S. K. (2009). Estimation of air pollutant emission loads from construction and operational activities of a port and harbour in Mumbai, India. Environmental monitoring and assessment, 159(1-4), 85. https://doi.org/10.1007/s10661008-0614-x.

[27] Kong, S., Han, B., Bai, Z., Chen, L., Shi, J., \& $\mathrm{Xu}, \mathrm{Z}$. (2010). Receptor modeling of PM2. 5, PM10 and TSP in different seasons and long-range transport analysis at a coastal site of Tianjin, China. Science of the Total Environment, 408(20), 4681-4694. https://doi.org/10.1016/j. scitotenv.2010.06.005.

[28] Keuken, M. P., Moerman, M., Voogt, M., Blom, M., Weijers, E. P., Röckmann, T., \& Dusek, U. (2013). Source contributions to PM2. 5 and PM10 at an urban background and a street location. Atmospheric Environment, 71, 26-35. https://doi.org/10.1016/j. atmosenv.2013.01.032.

[29] Pérez, Noemí, et al. (2016). Impact of harbour emissions on ambientPM10 and PM2. 5 in Barcelona (Spain): Evidences of secondary aerosol formation within the urban area. Science of the Total Environment, 571, 237-250. https://doi. org/10.1016/j.scitotenv.2016.07.025.

[30] Jaafari, J., Naddafi, K., Yunesian, M., Nabizadeh, R., Hassanvand, M. S., Ghozikali,M.G.,...\&Yaghmaeian,K.(2019). Characterization, risk assessment and potential source identification of PM10 in Tehran. Microchemical Journal, 154, 104533. https://doi.org/10.1016/j. microc.2019.104533.
[31] Kalafatoglu, E., Ors, N., Gozmen, T., Sain, S., Munlafalioglu, I. (1997). Air pollution contribution of some cement plants in Turkey. 10th Regional IUAPPA Conference, (pp. 191-196). Istanbul.

[32] Yatkın, S., \& Bayram, A. Bir çimento fabrikası çevresinde hava kalitesinin incelenmesi. Yanma ve Hava Kirliliği Kontrolü VI. Ulusal Sempozyumu, (pp. 403-412). Izmir.

[33] Ercan, Ö., Dinçer, F., Sarı, D., \& Ceylan, Ö. Kömür yakıtlı termik santral etki alanında PM10 ve çöken tozların tesis kurulum öncesi ve sonrası dağılımı. VII. Ulusal Hava Kirliliği ve Kontrolü Sempozyumu (pp. 388- 397). Antalya.

[34] Karaçoban, İ. (2018). Particle Matter Pollutıon Area Source Modelling (PhD Thesis). Selçuk University.

[35] Contini, D., Gambaro, A., Donateo, A., Cescon, P., Cesari, D., Merico, E., ... \& Citron, M. (2015). Inter-annual trend of the primary contribution of ship emissions to PM2. 5 concentrations in Venice (Italy): Efficiency of emissions mitigation strategies. Atmospheric Environment, 102, 183190. https://doi.org/10.1016/j. atmosenv.2014.11.065.

[36] Kuzu, S. L., Bilgili, L., \& Kiliç, A. (2020). Estimation and dispersion analysis of shipping emissions in Bandirma Port, Turkey. Environment, Development and Sustainability, 1-21. https://doi. org/10.1007/s10668-020-01057-6.

[37] Horst, T. W. (1983). A correction to the Gaussian source-depletion model. Precipitation Scavenging, Dry Deposition and Resuspension, 2, 12051217.

[38] Pasquill, F. (1976). Atmospheric Dispersion Parameters in Gaussian Plume Modeling. 2. Possible Requirements for Change in the Turner Workbook Values (No. EPA600-4-76-030B). 
[39] Sungur, K., A. \& Gönençgil, B., (1997). Çeşitli İklim Elemanlarının Hava Kirliliği Üzerine Etkileri. Ankara Üniversitesi Türkiye Coğrafyası Araştırma ve Uygulama Merkezi Dergisi, 6, 337-345.

[40] HEAL. (2018). Health and Environment Alliance. Linyit kömürü: sağllk etkileri ve sağllk sektöründen tavsiyeler. Retrieved November 26, 2019, from https://www.env-health.org/wpcontent/uploads/2018/12/HEALLignite-Briefing-TRweb.

[41] TÜíK. (2019). Türkiye İstatistik Kurumu: Temel Istatistikler. Retrieved November 30, 2019, from http://tuik. gov.tr/UstMenu.do?metod=temelist.

[42] Çevre ve Şehircilik Bakanlığı. (2018). Hava Kalitesi Haber Bültenleri. Çevre ve Şehircilik Bakanlığı. Retrieved December 26, 2019, from https://webdosya.csb. gov.tr/db/ced/icerikler/bultensubat-2018-20180413160608.pdf.

[43] World Health Organization (2018). Ambient (outdoor) air quality and health. Retrieved December 21, 2019, from https://www.who.int/en/newsroom/fact-sheets/detail/ambient(outdoor)- air-quality-and-health. 